\title{
自由表面をもつ層流せん断流中の球に働く抗力と揚力

\author{
DRAG AND LIFT ON SPHERES IN A FREE \\ SURFACE POISEUILLE FLOW
}

\author{
福 岡 捷 二**石 田 貴**.迯 目 英 正*** \\ By Shoji FUKUOKA, Takashi ISHIDA and Eisei NIGEME
}

\section{1. 序}

流体中の固体粒子に作用する流体力は, 通常 2 つの成 分に分解される．流れに平行な抗力（drag force）と流 れに直角な揚力（lift force）である. 粘性流体中の固体 粒子に作用寸る流体力は, ナビエ・ストークスの方程式 $(N-S$ 方程式）を適切な境界条件のもとに解き求める. しかし， N-S 方程式の慣性項は，速度について非線形 なため, 解析的に解が得られる流れはきわめて限定され る. レイノルズ数 $\left(R_{e}\right.$ 数) の小さい非常に遅い流れで は，慣性項は粘性項に比して無視でき（ストークス近 似), この場合には解が求まる ${ }^{1)}$. Stokes は, このよう な方法で最初に一様流中の球のまわりの軸対称流れを解 き，抗力を算定した. Ossen は，慣性項を限られた範囲 で考慮し (オセーン近似), Goldstein は, オセーンの方 法を改良し，抗力を求めている。しかし，これらは $N$ $S$ 方程式の線形化によって得られたもので, 解の適用範 囲は $R_{e}<2$ 程度に限定される. また， Saffman ${ }^{2)}$ Bretherton ${ }^{3)}$ によって指摘されているように慣性項を省 略した解は，運動方向に直角な力（揚力）が零となる問 題点をもつ。

このように，境界のない無限領域の非常に遅い流れの ような最も単純な場合でもその流れの中に球が存在する 場合には，解析的に取り扱える範囲に限度がある。にも かかわらず, 壁で制限された速度分布のある流れの中に 球が存在するときの抗力と揚力を算定することは, 粒子 浮遊流の運動を知るうえで重要である.この問題は, 特 に化学工学の分野で扱われる流動層上の流れ, 圧摧空気 による粉体輸送等に関連し多く研究されてきた.この場 合, 無限域のストークス抵抗, あるいはオセーン抵抗に

* 正会員 Ph.D 工博 東京工業大学助教授 工学部土木工 学科

** 正会員 工修 日本下水道事業団

*** 正会員 (株) 協和コンサルタンツ
補正をくわえ，境界のある有限域の抵抗を算定すること が多かった。

さて, 壁の存在は 2 つの異なった様式で流体力に影響 すると考えられる.

1）壁により付加される抵抗のため, 球と流体の間に 相対速度が生じる。

2）壁の存在は, 球のまわりの流況を変化させ, 流体 の慣性力の影響が無限域の場合と異なる。この影響は, 壁の付近で特に著しい。

Segré と Silberburg ${ }^{5)}$ は，管内ポアズイユ流中を浮 遊する小さな中立粒子が，管軸から 6 割の位置に集中し て運動することを示し, 球の運動に及ぼす揚力の重要性 を明確にした。

Saffman ${ }^{6)}$ は上述の 1) の場合, すなわち, 流体中の 固体粒子は, 壁によって直接には影響を受けないが, 流 速分布の影響を受ける場合の揚力について理論的に考察 した. その結果, 遅い速度 $V$ をもつ一様せん断流中を 運動する球は，運動方向に直角に揚力

$$
L=81.2 \mu V a^{2} \kappa^{1 / 2} / \nu^{1 / 2}
$$

を受けることを示した.ここに, $a$ は球の半径, $\kappa$ は速 度勾配である. Rubinow と Keller ${ }^{7}$ は, 遅い粘性流体 中を回転しながら運動する球に作用する抗力と揚力を Ossen 方程式にもとずいて解析した。すなわち,

抗力: $F=-6 \pi \mu a V\left[1+\frac{3}{8} R_{e}+O\left(R_{e}\right)\right]$

揚力: $L=\pi a^{3} \rho \Omega \times \boldsymbol{V}\left[1+O\left(R_{e}\right)\right]$

を求め, Ossen によって求められた抗力は, 回転があっ ても $R_{e}$ のオーダーまで補正の必要がないこと, 揚力の 主たる部分の第一項には, 粘性係数は関倸なく, ポテン シャル理論を用いた翼に働らく揚力と同型であること等 を明らかにした. これらが, $R_{e}$ 数の小さい層流せん断 流中に球が存在する時の抗力, 揚力に関する主要な研究 である.

一方, $R_{e}$ 数が比較的大きな $\left(R_{e}>10\right)$ 層流せん断流 
中の球のまわりの流れに関する解析的研究は, 非線型項 の重要性から, 著者らの知る限り存在せず, relaxation 法等を用いた数值解があるにすぎない妾. Fayonと Happel $^{9)}$, Young ${ }^{10)}$, Eichhorn と Small ${ }^{11)}$ らは, このよう な $R_{e}$ の範囲で壁の影響のある層流せん断流中の球に作 用する流体力の実験的研究を行った. Fayon らは，管 内ポアズイユ流れの中に軸から種々の距離に球を吊し， 抗力を測定し $R_{e}<40$ に対し実験式を提案した. Young は，傾斜管を上昇する層流中で流体力と鈞り合って底面 に接して静止している球に及ぼす抗力上揚力を測定し た.しかし, Young の測定值には管壁と球の摩摖の影 響が入っているため測定資料の信頼性はそしい。 Eichhorn らは, Young と同様に, 直径 $1.0 \mathrm{~cm}$ の円管を用 いて流量, 球の重量, 直径を変えながら壁から種々の距 離で流体力と球の水中重量を平衡させ, この状態で管の 傾斜角, 球の水中重量, 位置等を知ることによって粒子 $R_{e}$ 数が $(80 \sim 250)$ の範囲のポアズイユ流中の壁から各 位置での抗力, 揚力, 回転速度を求めた. 実験的に求め た抗力倸数, 揚力倸数, 無次元回転速度が粒子 $R_{e}$ 数や 無次元シアーパラメーターに対し検討されているが, 無 次元量の選び方や抗力および揚力に及ぼす球の回転の効 果など十分な考察がなされていないなど問題点を含む.

しかし, 速度勾配と壁の影響がある流れの中に球が固定 されずに自由な状態で存在する時の揚力の測定は彼等が 最初であり, 得られた実験結果の意義は大きい。

一般に, 固体粒子浮遊流では, 流体と固体の密度差の ために相対速度差が生じる. せん断流中で流体と球が相 対運動している時の球に作用寸る流体力を知ることは, 粒子浮遊流の力学特性を理解するらえで重要である. 本 研究はその第一段階として, 底面と水面で境界された層 流中に吊されて静止している球に作用する抗力と揚力を 測定し, 固定境界 (底面), 変形境界 (水面), 流速分布 の流体力に及ぼす影響を明らかにする.さらに円管内層 流での測定值 ${ }^{11)}$ 之著者らの開水路層流での測定值を比較 検討し, 抗力, 揚力の統一的な説明を試みる.

\section{2. 実験装置と実験方法}

\section{（1）実験装 置}

乱流中で球に作用する流体力を測定しょうとすると速 度変動のために流体力も大きく変動する. 本研究の目的 は, せん断流中の抗力と揚力を算定し, かつ境界の存在 と流速分布が流体力に如何なる影響を及ぼすかを調べる ことにあるので, 乱流変動に起因する影響を取り除いて 検討することが望ましい，そこで，流体としてグリセリ 二溶液 (温度 $10^{\circ} \mathrm{C}$ で比重 1.1974 , 動粘性係数 $\nu=53$
センチストークス）を用い，層流で実験を行った。グリ セリン溶液の動粘性係数は, 温度に敏感なため流体力の 測定時に頻繁に測温し, あらかじめオストワルド粘度計 で求めておいた動粘性係数と温度の関係より, その時の 正しい動粘性係数を求めた.

実験水路は, 長さ $200 \mathrm{~cm}$, 幅 $15 \mathrm{~cm}$, 高さ $10 \mathrm{~cm}$ の

表一1 球の直径とグリセリン中重量

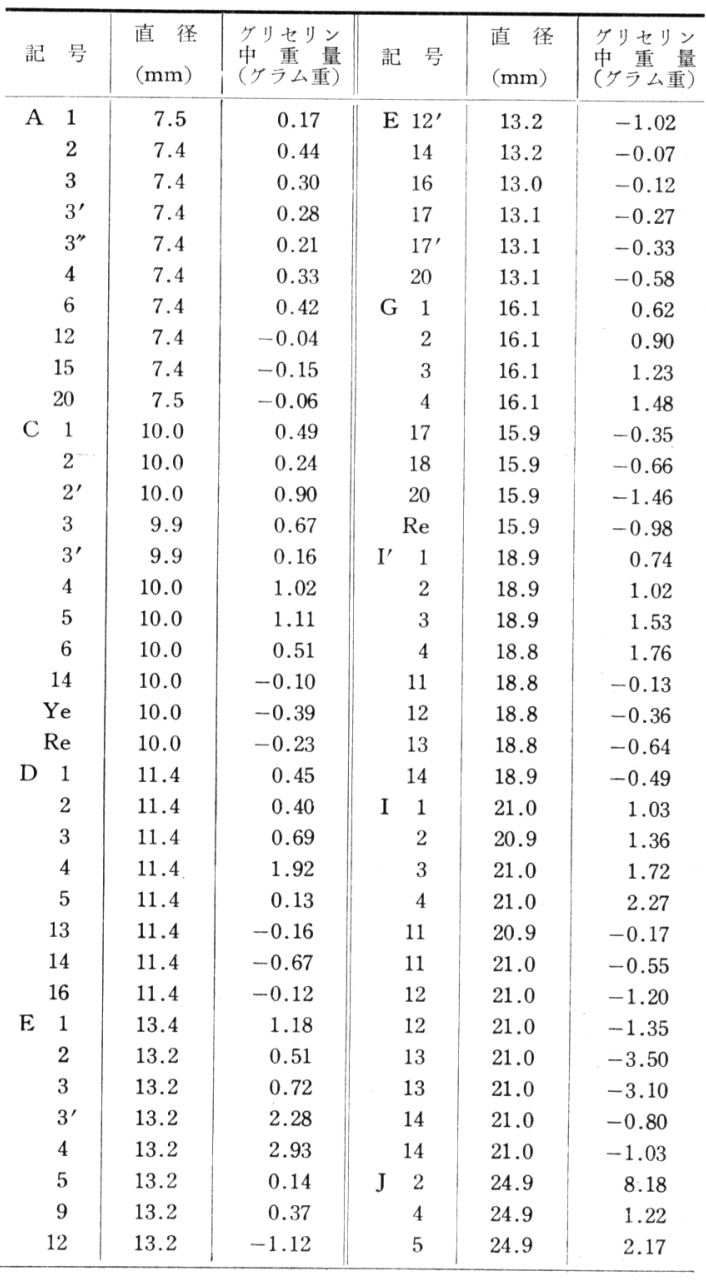

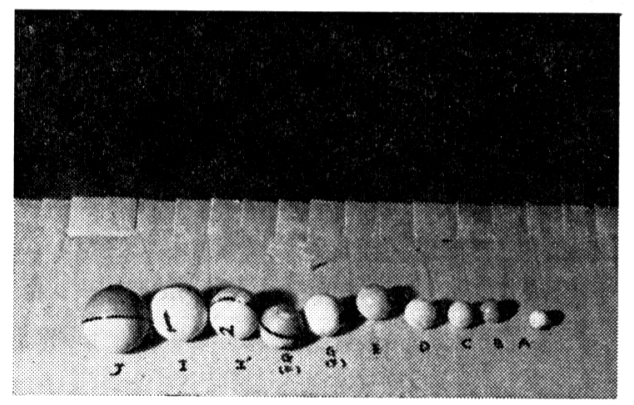

写真 -1 球 の - 覧 
アクリル製循環式開水路である．測定は，境界層 が水面まで到達し，流れが等流とみなせる区間で 行った. 実験は, 常に水深を $7.1 \mathrm{~cm}$ に保って行 われた. 用いた球は, 市販の玉うきでそれらを写 真一1 に示す.玉うきは, ほとんど球とみなして もよいものを用いた. 球は 8 種類で直径の小さい 方から順番に $\mathrm{A}, \mathrm{B}, \mathrm{C}, \cdots, \mathrm{J}$ と名うけた. 直径 $\mathrm{A}$ 〜 の球に油，グリセリン溶液，水，鉛玉などを

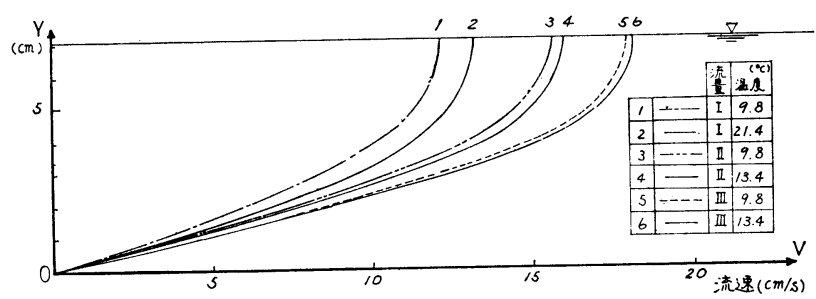

図一1 流速 分 布 重心が偏らないように玉うき内部につめ, それぞれの径 の球に対し 4〜10 個の異なる重量の球を製作した. 球の グリセリン溶液中重量は $0.1 \mathrm{mg}$ まで測定可能な直示天 秤を用いて秤量した．それぞれの球の直径とグリセリン 中重量を表一1に示す. 負のグリセリン中重量は球の密 度がグリセリン密度よりも小さいことを示す.

\section{（2）実験方法}

6 種類の異なった流量について, 球に作用する流体力 の測定を行った. 流速分布は, 等流区間の水路中央線上 で水素気泡発生装置を用いて写真撮影し読み取った。 図 一1に示すように, 流速は放物線分布をしていることが わかる. すなわち,

$$
\bar{u}=\frac{u}{u_{0}}=\left(2 \eta-\eta^{2}\right)
$$

ここに, $\eta=y / h, h=$ 水深, $u_{0}$ は表面流速で平均流速 $u_{m}$ と $u_{0}=1.5 u_{m}$ の関係にある.

次に球の抗力と揚力の測定法を述べる. 等流区間で図 -2のごとく，系を用いて球を下から支持したとき，支 点Oのまわりのモーメントの釣り合いより式 (2) が成立 する.

$$
F \times y_{c}+\int_{0}^{y_{c}-a} q_{1}(y) y d y-\left(L+W_{1}\right) x_{1}=0 \cdots(2)
$$

ここに, $F$ : 抗力, $L:$ 揚力, $y_{c}$ : 底から球の中心まで の高さ, $x_{1}$ : 糸の支点より水平方向の距離, $q_{1}(y)$ : 禾 に分布する単位長さあたりの抗力, $W_{1}$ : 球のグリセリ ン中重量, $a$ : 球の半径である. 球に作用する偶力は式 （2）に示されたモーメントに比較して小さく無視でき る.なぜならば，球と系の交点に接する平面に対し，糸 はすべての実験にわたって，ほぼ $90^{\circ}$ の角度をなしてい たためである. 次に, グリセリン中重量のみが異なる同 一径の球を同じ高さに支持したとき，流れは等流である ので球に作用する抗力, 揚力は等しい. したがって次式 が成立する。

$$
F \times y_{c}+\int_{0}^{y_{c}-a} q_{i}(y) y d y-\left(L+W_{i}\right) x_{i}=0 \cdots
$$

よって,これら一連の $\left(y_{c}, W_{i}, x_{i}\right)$ の測定により, $F$ と $L$ を求めることができる. しかし, 球を図一2のよ らに下から支持すると水表面に近ずくにつれて, 糸の抗 力の影響が比較的大きくなる.この場合には図一3に示

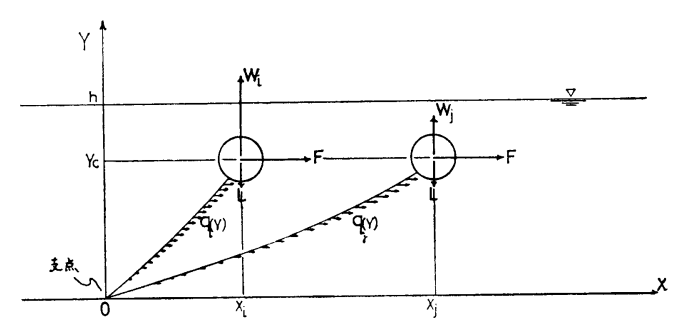

図一2 球の支持方式（下から支持）

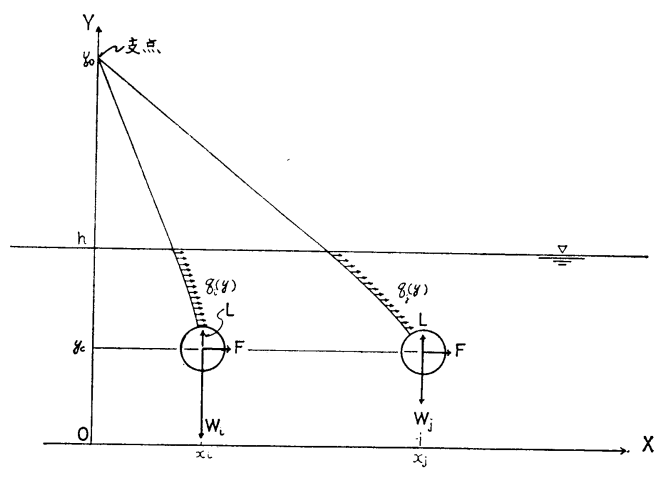

図一3 球の支持方式（上から支持）

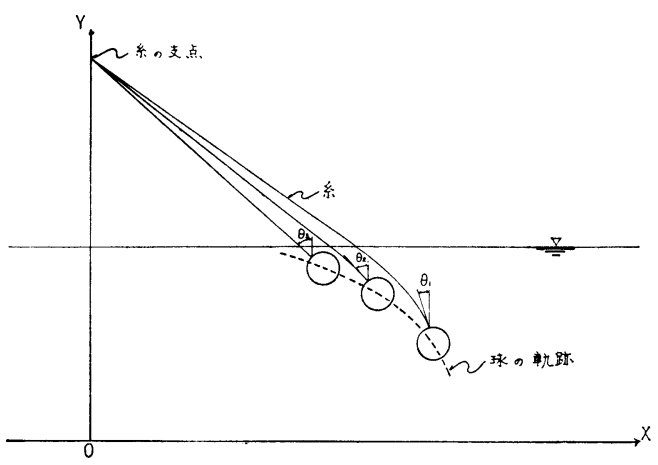

図一4 球の動く軌 跡

すように球を上方より支持する.すなわち, 球の支持方 式を変えて同一の水理条件で測定を行い実験の信頼性を 高めるようにした．上から支持した場合のモーメントの 釣り合い式は式 (4) で与えられる.

$$
\begin{gathered}
F \times\left(y_{0}-y_{c}\right)+\int_{y_{c}+a}^{h} q_{1}(y)\left(y_{0}-y\right) d y \\
-\left(W_{1}-L\right) x_{1}=0
\end{gathered}
$$




$$
\left.\begin{array}{c}
F \times\left(y_{0}-y_{c}\right)+\int_{y_{c}+a}^{h} q_{i}(y)\left(y_{0}-y\right) d y \\
-\left(W_{i} L\right) x_{i}=0
\end{array}\right\} \cdots(4)
$$

ここに, $y_{0}$ : 底から糸の支点までの高さ, $h:$ 水深. 図 -2 の型式で球を支持したとき，図一4に模式的に示す ように, 球は支点を中心とし, 糸の長さ $l$ を半径とする 円周上を動く. 角 $\theta$ に対し安定な釣り合い状態にあると き, 球の静止する場所は, 支点の位置, 糸の長さ $l_{i}$, $F(y), L(y), W_{i}$ に応じ一意的に定まる.したがって， 糸の長さ $l_{i}$ を変えることによって任意の位置 $y$ に球を 静止させ，この状態での球の左端，下端を透明紙上に写 し取り，球の半径を加えて中心座標を読夕取った。この ようにして得た離散的な点を連ね, 球の動く軌跡を決定 する，測定の一例を図一5 (a)，(b)に示す，これより任 意の高さ $y_{c}$ における $x_{i}$ 座標を決定することができ る.これらの軌跡の測定は, 流れが二次元とみなせる水 路中央線上で行った.

\section{3. 球の抗力と揚カの算定}

\section{(1) 支持糸の抗力}

式 (2)，(3)，(4)により球に作用する抗力，揚 力を計算するには系に作用する分布荷重 $q_{i}(y)$ を 決める必要がある. 用いた糸は 0.2 号の釣糸で直 径 6/100 mm ときわめて細く, 加わる抗力も高々 数十 $\mathrm{mg}$ 重である.これは, 最小の球 $\mathrm{A}$ を除い ては球自身に作用する流体力に比し十分小さい. したがって次の仮定のもとに糸に作用する抗力を 算定する.

（i）系の弹性，重量は無視できる.

(ii ） 采は流下方向の投影面積に比例する抗力 のみを受け, 系の抗力係数は一様流中の円柱の抗 力係数で表わすことができる.

これらの仮定より, 分布荷重は次式で与えられ る.

$$
q_{i}(y)=C_{D} \frac{1}{2} \rho u(y)^{2} d
$$

ここに, $C_{D}$ : 円柱の抗力係数, $d$ : 糸の直径, $\rho:$ 流体の密度. 一様流中の非常に小さい $R_{e}$ 数 に対する円柱の抗力は Stokes 近似では無限遠点 の境界条件を満足しないためOssen 近似にもと ずいて $\mathrm{Lamb}^{12)}$ によって理論的に求められてい る.

すなわち,

$$
C_{D}=\frac{8 \pi}{R_{e}}\left[\varepsilon+O\left(R_{e} \varepsilon\right)\right]
$$

ここに，

$$
\varepsilon=\frac{1}{\frac{1}{2}-\ln \left(\frac{r_{0} R_{e}}{8}\right)}, R_{e}=\frac{u d}{\nu}, r_{0}=e^{r}=1.781
$$

これまでに実測された円柱の抗力は $R_{e}=0.06$ が最小 で, これ以下の $R_{e}$ 数での実測は存在しないが, $R_{e}$ が $10^{-5}$ の球についてなされた抗力の実測から類推して, Ossen 近似による解は $R_{e}<0.06$ の範囲に対しても成 立することが知られている(2),13). 本実験の範囲では $R_{e}$ 〜 0.1 であるので, 式 (6) は第一項のみを考慮すればよ い.このとき, 式 (5) は

$$
q_{i}(y)=4 \pi \mu u(y) \cdot \frac{1}{\frac{1}{2}-\ln \left(\frac{r_{0} R_{e}}{8}\right)}
$$

となる. 球に作用する流体力は式（3）または（4）から 式 (7) による采に作用する抗力を差し引くことによって 求めることができる.

\section{（2）球の抗力, 揚力の算定}

$\mathrm{A} \sim \mathrm{J}$ の各球について $4 \sim 10$ 個重量の異なる球を用い 
て, 各球について 数組の測定を行った. 式（3）または (4) より $F, L$ に関する式をたて 2 組の観測值を用いて $F$ と $L$ を求める. 式 (3) で (i) 番目と $(i+k)$ 番目の 測定值を用いると

$$
\begin{aligned}
& F=\frac{1}{y_{c}}\left[-\frac{x_{i} x_{i+k}\left(W_{i}-W_{i+k}\right)}{x_{i}-x_{i+k}}-\int_{0}^{y_{c}-a} q_{i}(y) y d y\right] \\
& L=-\frac{W_{i} x_{i}-W_{i+k} \cdot x_{i+k}}{x_{i}-x_{i+k}}
\end{aligned}
$$

同様に式（4）により

$$
\begin{aligned}
& F=\frac{1}{y_{0}-y_{c}}\left[\frac{x_{i} x_{i+k}\left(W_{i}-W_{i+k}\right)}{x_{i}-x_{i+k}}\right. \\
& \left.-\int_{y_{c}+a}^{h} q(y)\left(y_{0}-y\right) d y\right] \\
& L=\frac{W_{i} x_{i}-W_{i+k} x_{i+k}}{x_{i}-x_{i+k}}
\end{aligned}
$$

このようにして計算したものに系統的誤差があらわれ たときにそのデータを除去し, 残りの計算值の平均をも って，Fと $L$ とした. また式 (3)，(4) を観測 方程式として, 最小自乗法を適用して求めた $F$ と $L$ は，第一の方法とほとんど違いは現われな かった.

\section{4. 実験結果と考察}

球の抗力, 揚力と水深の関係を, 球径をパラメ 一ターとして示したのが 図一6, 図一7である. 図中黒点は球の中心を示し，実線は下から支持， 点線は上から支持した場合である．点線と実線 は，球径が同一であれば，同一高さでは一致すべ きものであるがわずかにずれている．この理由 は，測定に時間がかかるため，測定中にグリセリ ン溶液の温度が変化し, そのため流体力にわずか な差が生じること，支持糸の抗力の補正に小さな 誤差を伴うこと, 両球は平均的にみて直径が同じ であるが同一球ではないことによる，しかし，測 定のむずかしさ，および測定值に影響する多くの 要因を考慮すると測定值の精度は非常によいとい える。

\section{（1）境界のある層流せん断流中の球の抗力}

一様流中の球の抗力係数の定義に倣い，せん断 流中の抗力係数を球の中心にあたる流速 $u_{c}$ を用 いて次のように表示する.

$$
C_{D C}=\frac{F}{\frac{1}{2} \rho u_{c}{ }^{2} \pi a^{2}}
$$

このとき, せん断流中で静止している球の抗力係 数 $C_{D C}$ は, 粒子レイノルズ数 $R_{e c}=u_{c} \cdot d_{s} / \nu$, 水
深と底面から粒子の中心までの距離の比, $y_{c} / h$, 水深と 粒径の比 $h / d_{s}$ の関数

$$
C_{D C}=f_{1}\left(R_{e c}, \frac{y_{c}}{h}, \frac{d_{s}}{h}\right)
$$

または, 式 (1) の速度分布形を $y$ で微分して, 相対水 深を速度勾配の無次元形で書き表わすと,

$$
C_{D C}=f_{2}\left(R_{e c}, \frac{h}{u_{0}} \frac{d u}{d y}, \frac{d_{s}}{h}\right)
$$

で与えられる. 式（11）または式（12）をみると，せん 断流中の球の抗力係数は，一様流中の抗力係数と異なる ことが予想される。

図一8 は, 式 $(10)$ で定義した $C_{D C}$ と $R_{e c}$ の関係を 示す. 当然のことながら $C_{D C}$ は $R_{e c}$ と一義的な関係に なく, 球径, 流量等によって分れることを示している. 図中には, 比較のため, 一様流中の球の抗力係数 $C_{D O}$

$$
C_{D O}=\frac{24}{R_{e}}+\frac{3}{\sqrt{R_{e}}}+0.34
$$

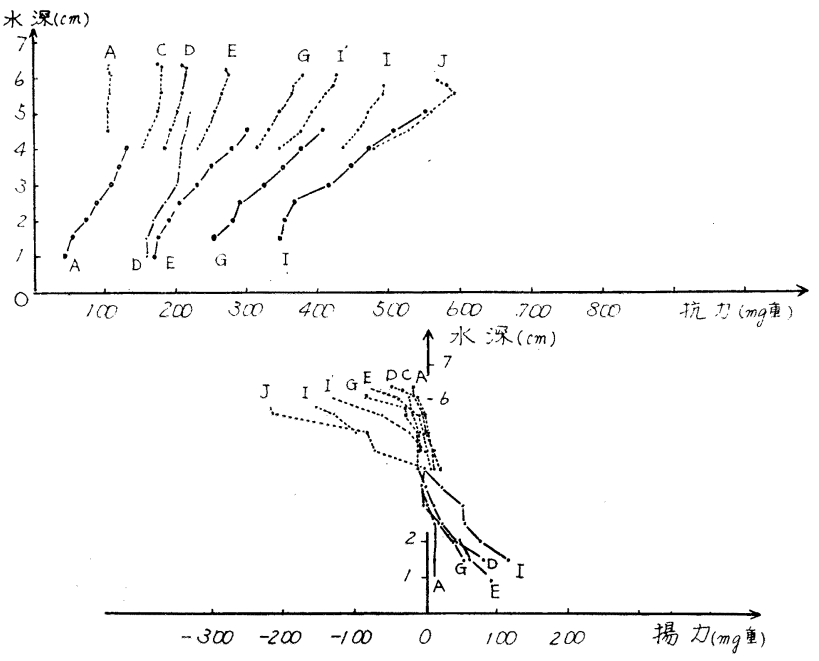

\section{図一6 抗力・揚力の実測值（流量 I）}
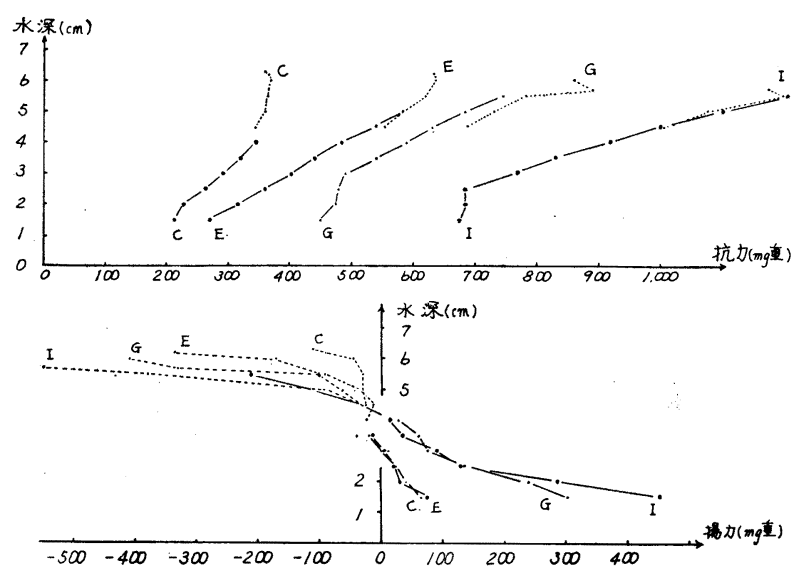

図-7 抗力・揚力の実測值（流量 III） 
も示す ${ }^{14)}$.

さて, 図-8 で特定の流量で特定の球の $C_{D C}$ と $R_{e c}$ の関係に注目する。この曲線上で $R_{e c}$ が増大するとき は, 球は水面方向に移動し, $u_{c}$ が増大, $d u / d y$ が減少 する.このとき, 球の抗力には速度勾配の影響が減じ， 一様流中のそれに漸近すると考えられる. しかし，開水

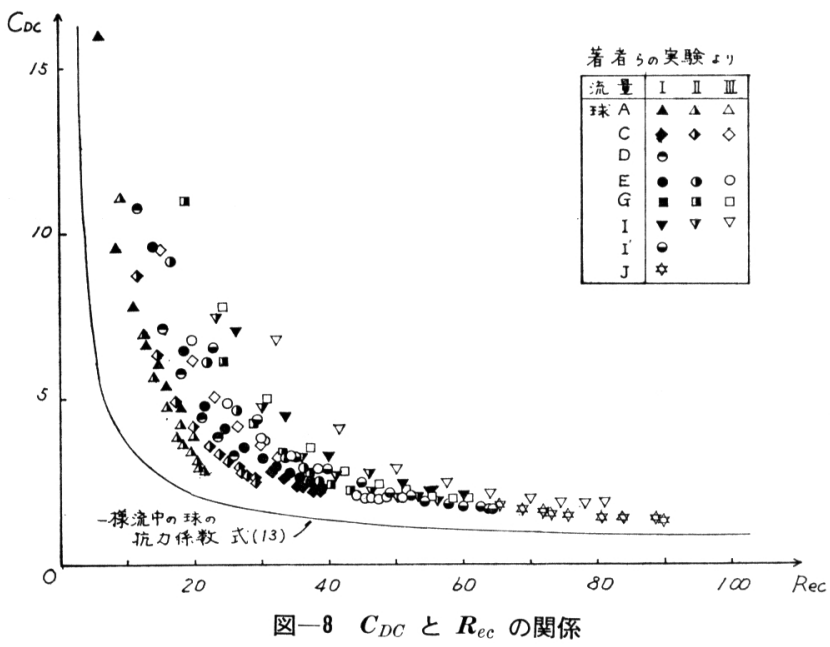

路流の場合には, 球が水面に近ずくにつれて水面が変形 し造波抵抗が大きくなる。この結果， $R_{e_{c}}$ が大きくなる ときの $C_{D C}$ は，一様流中の抗力係数に造波抵抗係数を くわえたものに近い值をとる. 写真一2 2 , 球 I が流体 中の種々の高さに吊されているときに板に描いた平行線 を水面に反射させ，水面の変形を写真撮影したもので女 る. 写真一2 (1) は, 球の中心が水底から $3.0 \mathrm{~cm}$ の位置にあるときのもので水面の変形はほとんど 認められないが，写真一2 (2) に示すよらに， $y_{c}$ $=3.5 \mathrm{~cm}$ では小さな変形が認められ，以下順次 水面に近うくにつれて水面の変形，したがって造 波抵抗が増大寸ることがわかる。一方， $R_{e c}$ が小 さい方向へ移動するときは，球が水底近くに移動 ᄂ, $u_{c}$ 法減少, $d u / d y$ 増大寸る. 抗力には速 度勾配と壁の影響が顕著に表われ，一様流の抗力 倸数に比して大きくなることがわかる.

次に, 流量を変化させ, 底から球の中心までの 高さを一定に保ちながら球の径を変化させたとき (このとき，それぞれの流量に対し速度勾配は一 定）の $C_{D C}$ と $R_{e c}$ の関係を図一9 亿示す. 流量 が異なると $R_{e c}, d u / d y$ が同じでも，このときと

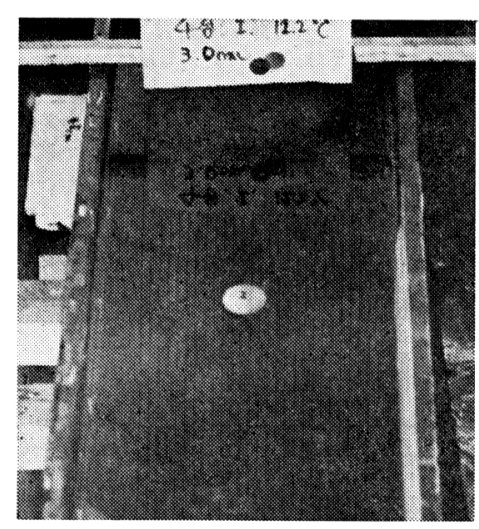

(1) $y_{c}=3.0 \mathrm{~cm}$

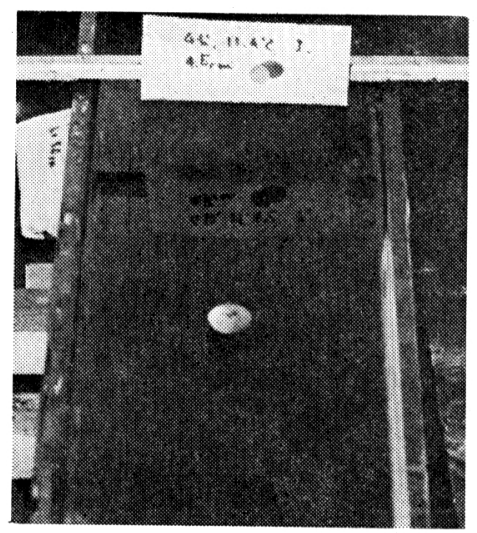

(4) $y_{c}=4.5 \mathrm{~cm}$

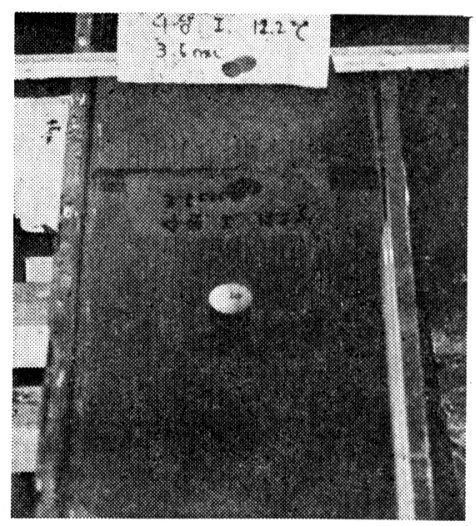

(2) $y_{c}=3.5 \mathrm{~cm}$

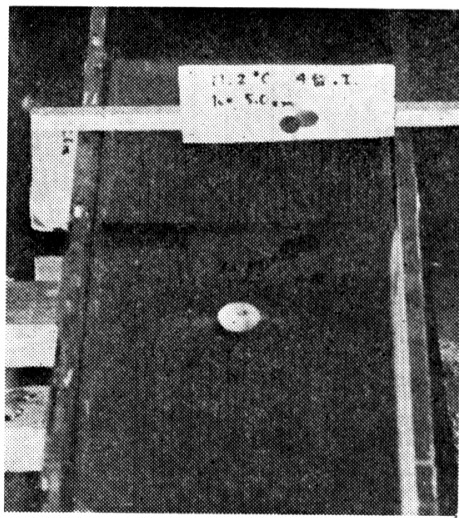

(5) $y_{C}=5.0 \mathrm{~cm}$

写真一2 球による水面の変形状況 (球 I)

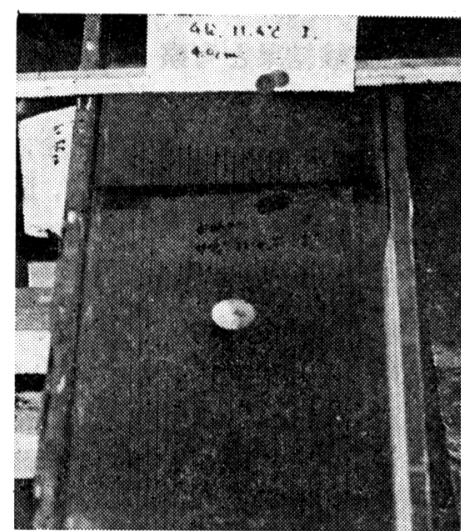

(3) $y_{C}=4.0 \mathrm{~cm}$

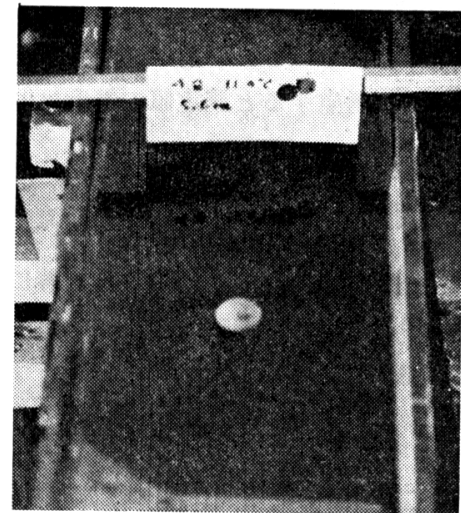

(6) $y_{c}=5.6 \mathrm{~cm}$ 


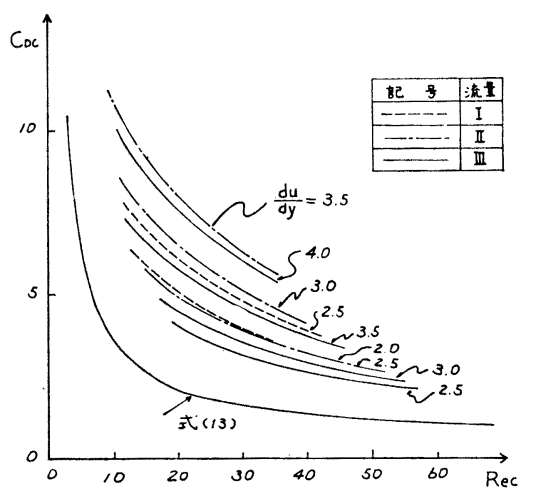

图一9 $C_{D C}$ に及ぼす速度勾配の効果

る $C_{D C}$ の值は異なる.これは, 流量が大のとき と小のときでは, 同じ $d u / d y$ のあらわれる位置 は, 流量が大のときのほらが小のときより壁から 遠くなるためである.したがって, 図一9 は, 抗力に及 ぼす速度勾配の影響をよく捕えてはいるが壁からの距離 が考虑されていず, 不十分である.ささ, 式 (1)を 微分すると

$$
\frac{d \bar{u}}{d \eta}=\frac{h}{u_{0}} \frac{d u}{d y}=2(1-\eta)
$$

となる. 式 (14) によると, $h$ が一定のもとで壁から球 の中心までの距離を一定 $\left(\eta_{c}=\right.$ 一定) にとると, 代表流 速 $u_{0}$ （または流量）と速度勾配でつくられた無次元速度 勾配 $d \bar{u} / d \eta$ が一定になる.したがって, 速度勾配その ものでなく, 無次元速度勾配に関係する壁からの距離を パラメーターに選ぶと, 図一9 で示された問題点は解決 されると思われる。図一10 は，このような考えのもと に整理されたものである.図中の破線は， $y_{c}$ (または $\eta_{c}$ ) が一定のものについて, 実測值の中心を通るようにひい たものであり, 矢印は, 本来測定值が属すべきグループ を示している. 式 (11) または, 式 (12) が示すように $C_{D C}$ には， $d_{s} / h$ も影響すると思われる. 本研究では, 実験全体を通じて水深を一定に保ち球径を変化させて, $0.11<d_{s} / h<0.3$ の範囲で実験を行った. 図一10よ り, 壁のごく近くを除くと, 等しい $R_{e c}$ と $\eta_{c}$ をもち, 球径のみが異なる（すなわち $d_{s} / h$ が異なる） 2 つの球 の $C_{D C}$ の值は, ほぼ等しく, 本実験の範囲では $d_{s} / h$ は $\eta_{c}$ と $R_{e c}$ ほど $C_{D C}$ には重要でないことがわかる.これ より $R_{e c}$ と $\eta_{c}$ を知るとほぼ一義的に $C_{D C}$ が求まる.す なわち, 流体の物理特性と流量が既知のポアズイユ流中 の任意の位置に, ある大きさの球が存在するとき, $u_{0}$ ま たは $u_{m}$ が既知であるので, 式 (1) より $u_{c}$, したがっ て $R_{e c}$ が決まりこれと $\eta_{c}$ より $C_{D C}$ を求めることができ る.

図一10 では, 壁の付近 $\left(\eta_{c} \fallingdotseq 0.2\right)$ では, 他の位置に 比し，測定值のばらつきがやや大きい．このばらつきの

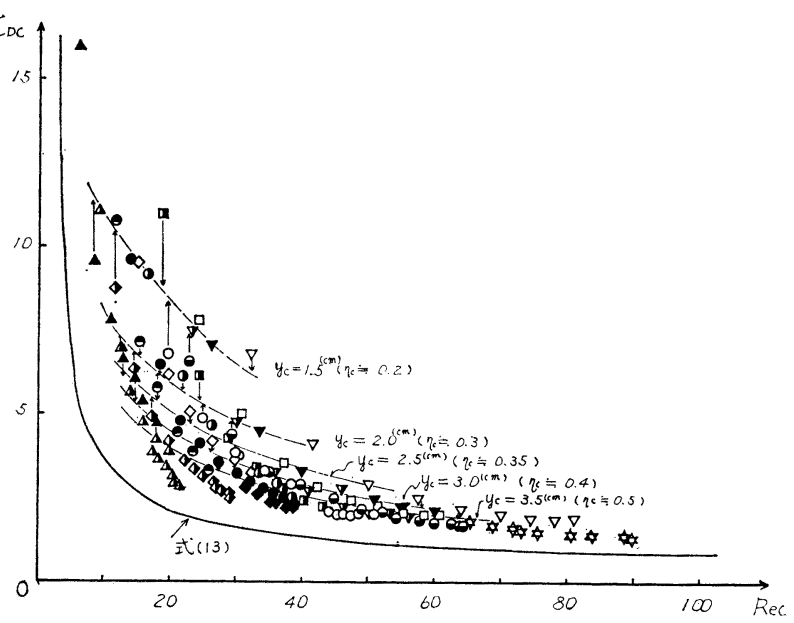

図一10 壁と速度勾配の影響のあるせん断流中の抗力係数

最大の理由は, 壁の近くでは, 壁から球の中心までの距 離 $y_{c}$ と球の半径 $a$ の相対的な大きさ $\left(\eta_{c} \fallingdotseq 0.2\right.$ では $\left.1.2<y_{c} / a<4\right)$ によって, 球のまわりの流れが影響さ れ, 圧力分布が変化するためであり, 第二の理由は, 壁 の近くでは抗力が小さいため, 測定値に含まれる誤差が 相対的に大きくなるためである. しかし，図一10は， 壁の影響が強い層流せん断流中の球の抵抗特性を知るう えで重要である.

図一11 は，Eichhorn と Small による円管内層流中 での回転自由な球の抗力係数と, 著者らによるほぼ同じ $R_{e c}$ 範囲 $\left(R_{e c}>50\right)$ での静止球の抗力係数の測定値の 比較を示す.

この図は, 壁の存在と球の回転が, 抗力にどのように 影響するかを理解するのに役立つ. Eichhorn らのデー 夕の横の数字は, 回転角速度 $(\mathrm{rad} / \mathrm{sec})$ を示す. 回転数 0 は, 管の中心軸上に球が存在し, 回転数増大とともに 管壁方向に球が移動することを意味している. 図一11 によれば, Sphere No. 1 と Sphere No. 2 の実験は, 球の回転数が小さいにもかかわらず, 著者らによる同じ $R_{e c}$ 数の静止球の実験值よりも $C_{D C}$ がかなり大きく, Sphere No. 3 と No. 4 の実験は, 逆に球の回転数が 大きいにもかかわらず, 静止球の実験值とほぼ同一の $C_{D C}$ の値をもつ. この理由は, Sphere No. 1 と No. 2 を用いた実験では, 管径と球径の比 $D / d_{s}$ が, それぞれ 3.3 と 4.5 で, Sphere No. 3 と No. 4 の実験 $\left(D / d_{s}\right.$ 〜7）に比して，管壁が球のまわりの流れに影響し，流 れの慣性力の影響が大きくなったためである.しかし, 球 の回転は，壁の影響ほど抗力には影響しない。このこと は, 序論で述べたように, 球の抗力には, 回転がそれほ ど影響しないという Rubinow ら ${ }^{7)}$ の結論が $R_{e c}>50$ の 層流でも大筋に扔いて成立していることを示しているよ うにみえる.しかし, Eichhorn らの測定值は, 壁の影 


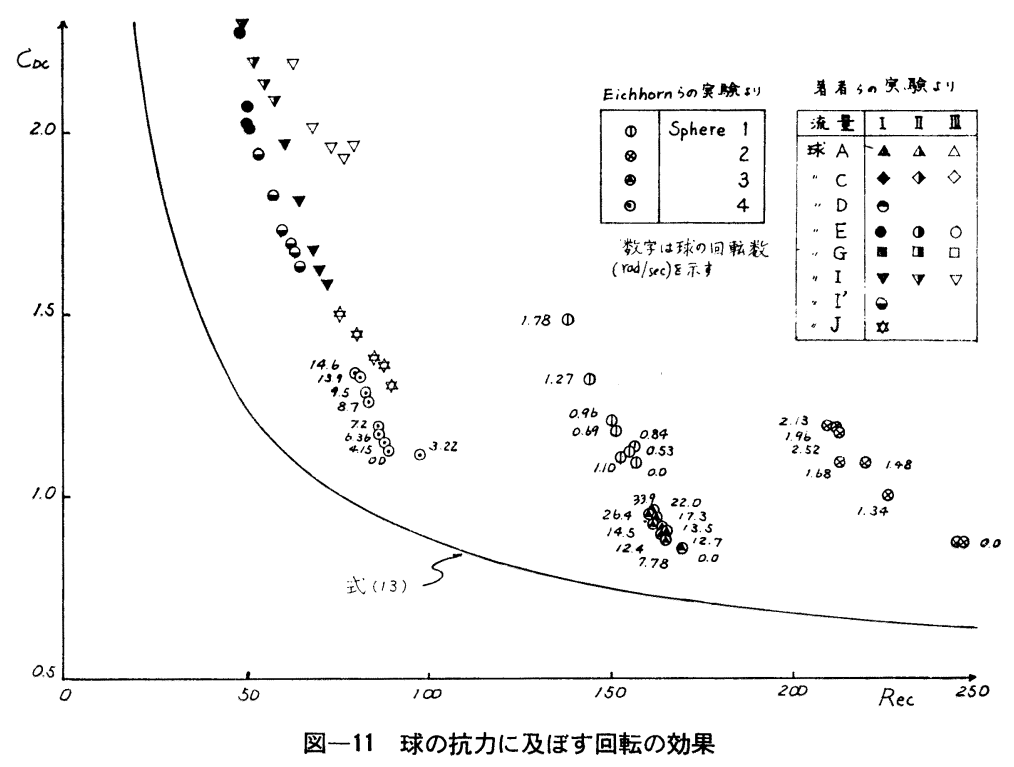

流の特性量から構成された無次元 量を横軸に選んで整理したものが 図一12 である. 著者らの実測值 は, $\left(C_{D C}-C_{D O}\right)$ の值が,

$$
\frac{d u}{d y} \frac{d_{s}}{u_{c}} \frac{1}{\left(R_{e c}\right)^{2}}<10^{-3}
$$

では, 全体的な傾向と若干異なり $\left(C_{D C}-C_{D O}\right)$ の值が やや大きく なる.この理由は, $10^{-3}$ 以下で は, 球が水面の付近にあり, 造波 抵抗が加わるためである. 著者ら の測定值によれば, 球の抗力係数 は近似的に次式で表わすことがで きる.

$$
\begin{aligned}
& \left(C_{D C}-C_{D O}\right) \\
& =32\left\{\left(\frac{d u}{d y}\right)\left(\frac{d_{s}}{u_{c}}\right) \frac{1}{\left(R_{e c}\right)^{2}}\right\}^{1 / 2}
\end{aligned}
$$

響と球の回転が加わった抵抗であるので，両者の影響を 分離した実験によって,ここで得られた定性的な結論を 確認する必要がある.

さて, 図一10 は, 壁と速度勾配の影響が卓越する流 れの中に球が存在するときの抗力について有用な情報を 与えるが, すべての $y_{c}$ での $C_{D C}$ を求めるためには, 図一6，7 を用いてすべての $\eta_{c}$ について図一10を完成 しなければならない。したがって, 図一10の表示はせ ん断流中の球の抗力係数を統一的に考える5えで本質的 ではあるが実用的に不便である.そこで, せん断流中の 球の抗力係数 $C_{D C}$ から，これと同じ $R_{e}$ をもつ一様流 中の球の抗力係数 $C_{D O}$ を差し引いたもの, 寸なわち壁 と速度勾配のみに起因する抗力係数 $\left(C_{D C}-C_{D O}\right)$ を縦 軸に, 球径, 速度分布, 壁の影響を考慮に入れたせん断

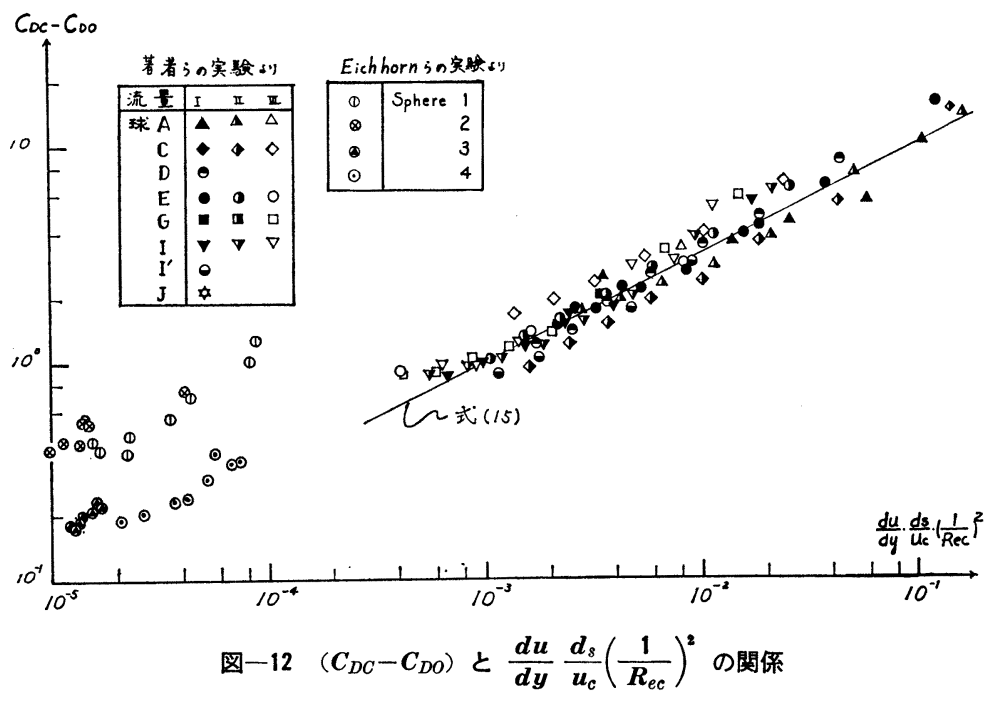

図一12には, Eichhorn らの実験值もプロットされて いる. Sphere No. $3\left(D / d_{s}=6.8\right)$ と Sphere No. 4 $\left(D / d_{s}=6.9\right)$ は, ともにほぼ式 (15) の関係を満足して いる. 一方 Sphere No. $1\left(D / d_{s}=3.3\right)$ と Sphere No. $2\left(D / d_{s}=4.5\right)$ は式 (15) で示される関係よりも大きい 值を示している. これは, 前述のように, Sphere No. 1 を用いた実験では, 管径と球径の比 $D / d_{s}$ が他に比して 小さく，管壁の影響が大きいためである. Sphere No. 2 も Sphere No. 1 ほどではないが, 管壁の影響が大き く, しかも $R_{e c} \approx 220$ で著者らや Spheres No. 3, No. 4 の $R_{e c}$ よりも大きいため, 回転のない静止球にたいし て見出された式（15）が成りたたないためと思われる.

\section{（2）境界のある層流せん断流中の球の揚力}

層流せん断流中に球が存在した とき,この球に働らく揚力は, 次 の 2 種類からなると考えられる.

(i ) 球の存在のため流線の曲 がりにより生ずるもの

(ii） せん断流中で球の回転運 動により生ずるもの

一般的には，この 2 つの力の合 成されたものが揚力であるが，序 でも述べたように, 境界の存在は (i), (ii) の効果を高め, 無限領域 中の球の揚力よりも大きくなる.

さらに, 本研究で取り扱ってい る自由表面のある層流では, 変形 境界 (自由表面) が抗力に影響し たと同様に揚力にも影響すると思 
われる. 本節では，これらの点に着目し，境界のある流 れの中での揚力について調べる.

揚力の実測值を示す 図一6,7 によれば,水深 $y_{c}=3.5$ $\mathrm{cm}$ 付近で揚力の符号が変化しているのが認められる. すなわち,この位置より上では, 揚力は下向きに働き, 下では上向きに働らく，慣性力と速度勾配が重要な流れ の場では, 球に上向き揚力が生ずることはいらまでもな い. 一方, 下向き揚力には, 水面の存在が不可欠であ り,この力は, 球が存在することによる水面の変形によ って及ぼされる反力と考えられる. 両者の力は逆方向に 働くので，それらの重㸚合せとして 図一6，7 の揚力が 観測される. 水面と底面の揚力に対する影響の度合は, 球の大きさによって異なり, 大きな球の方が揚力の符号 の変化する点は，水面方向に寄る傾向がある.

揚力係数を抗力係数と同様に次式で定義する.

$$
C_{L}=\frac{L}{\frac{1}{2} \rho u_{c}^{2} \pi a^{2}} .
$$

せん断流中の揚力係数も抗力倸数と同様に式 (11) また は（12）の関数関係で表わされる.

(a) 負の揚力

写真一2 が示すように, 球 I が流体中にあるとき, $y_{c}$ $=3.5 \mathrm{~cm}$ 付近で水面の変形が現われ始め, 球が水面に 近づくにつれて変形は顕著になる. 図一7は， $y_{c}=3.5$ $\mathrm{cm}$ 付近で揚力が負になることを示す. 水面の変形開始 点が揚力の負になる点とほぼ一致し, 変形増大とともに

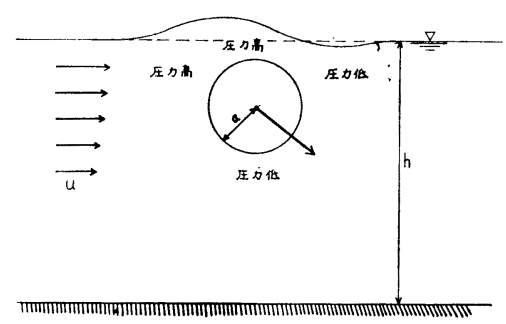

図一13 水面付近の球のまわりの圧力分布

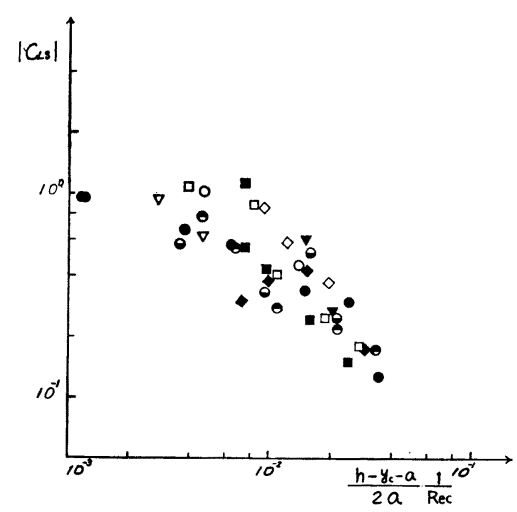

図一14 水面からの負の揚力
負の揚力が大きくなっている，図一13 は，球が水面に 近づいたときの水面の変形および周囲の圧力状態を模式 的に示す.このような場合, 球は, 図示したような“力” を受けると考えられる.この水面からの反力に起因する 負の揚力に対し, 式 (16) で定義される揚力係数 $C_{L S}$ と, 球が流体中に存在しないときの乱されていない水深 から球の上面までの距離を球径で除し，それに $1 / R_{e c}$ を 乗じた無次元量の関係を 図一14 に示寸.

これにより次のことがいえる. 水面からの反力が比較 的小さいところ,すなわち,球が水面から遠いところでは 流量, 球径等に無関係に $-C_{L S}$ と $\left(h-y_{c}-a\right) \cdot 1 / 2 a \cdot R_{e c}$ はほぼ一定の関係にあるが，水面に球が近づくにつれて 測定值は，散らばる傾向がある。この領域では，流れの 慣性力が大きいため, 球による水面の変形も大きい，し たがって，hが一定といら仮定は不十分であり，むしろ $h$ の変化量が重要である. 図一14 から判断して, 負の 揚力が水面の変形の影響で起っていることは確かであ る.しかし，負の揚力に対し次のような考え方があるこ ともここで付記しておく，序で述べたょうに，管内ポア ズイユ流中の中立粒子が半径の 6 割の位置に集中し運動 することを, Segré と Silberburg ${ }^{5)}$ が実験的に見い出し ており，これは，古くから知られている血管中の赤血球 の挙動とともに，球に作用する流れと直角方向の力に関 して興味ある問題を提起している.この事実は，球に対 し壁から中心方向に，また中心からは壁方向に力が働い ているとも考えることができ, 水面の存在がなくても, 流れの流速分布と粒子の相互作用でこのような揚力の場 が決定する可能性もある。しかし，Segré らの結果は低 レイノルズ数で見い出されたものであり， Eichhorn $ら^{11)}$ による実験 $\left(80<R_{e c}<250\right)$ では，このような特 異な現象は観測されなかった。

(b) 正の揚力

図一15 は, 正の揚力に関する揚力係数 $C_{L B}$ と壁の 影響, 流速分布を考慮に入れたせん断流の無次元特性量 $\frac{d u}{d y} \frac{d_{s}}{u_{c}} \frac{1}{R_{e c}}$

の関倸を示す．回転のない正の揚力に関する著者らの実 験值によれば, $C_{L B}$ は, 無次元量

$$
\frac{d u}{d y} \frac{d_{s}}{u_{c}} \frac{1}{R_{e c}}
$$

によって一義的に決定され，

$$
C_{L B}=\frac{L_{B}}{\frac{1}{2} \rho u_{c}{ }^{2} \pi a^{2}}=18\left(\frac{d u}{d y} \frac{d_{s}}{u_{c}} \frac{1}{R_{e c}}\right)^{2} .
$$

で与えられる。

図中に，Eichhorn らの実測值も再整理してプロット してある. 回転のある球の揚力係数に関する Eichhorn らの測定値は，著者らの測定值より数段大きい。この理 

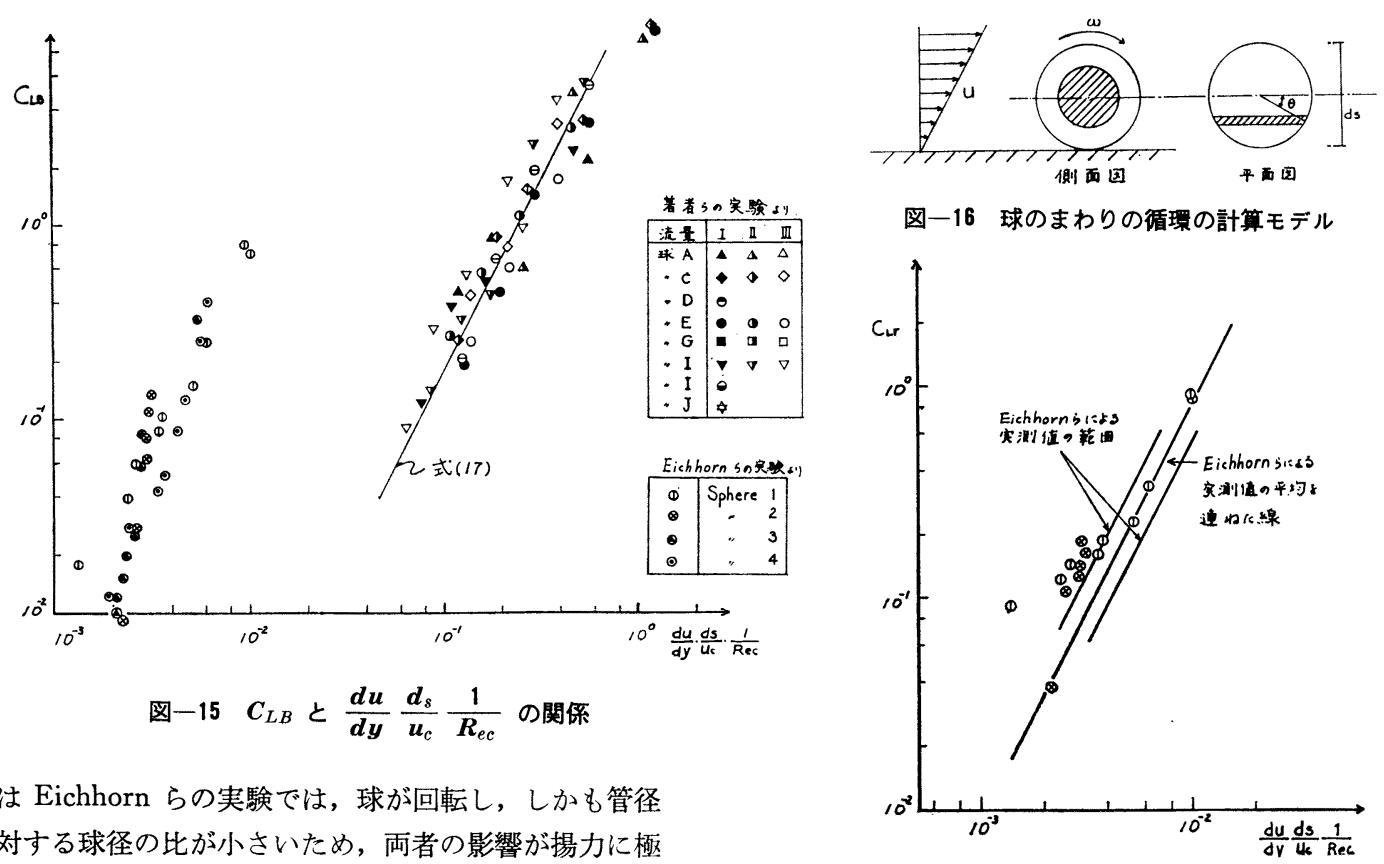

由は Eichhorn らの実験では，球が回転し，しかも管径 に対する球径の比が小さいため，両者の影響が揚力に極 端に効くためである.しかし，図一12 が示すように， 図一17球の回転による揚力

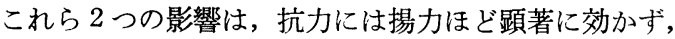
Eichhorn らと著者らの実測值が，ほぼ同じ抗力特性を 示していることは興味深い.

次に，揚力に及ぼす球の回転効果を考えてみる．いま 球は滑らず，回転するものとする. 図一16 のように球 を微小厚さをもった円板の集合と考えて解析を進める. 球は, 小さいものと考え円板の上端と下端の間の流速分 布を直線で近似する.

$$
\frac{d u}{d y}=\beta=\text { 一定 }
$$

球が回転角速度 $\omega(\mathrm{rad} / \mathrm{sec})$ で回転するものとすると, 円板の上端，下端の速度は，それぞれ次式で与えられ る.

$$
\begin{aligned}
& u_{u}=\beta \frac{d_{s}}{2}(1+\cos \theta)-\left(\frac{d_{s}}{2} \omega+\frac{d_{s}}{2} \cos \theta \cdot \omega\right) \\
& u_{l}=\beta \frac{d_{s}}{2}(1-\cos \theta)-\left(\frac{d_{s}}{2} \omega-\frac{d_{s}}{2} \cos \theta \cdot \omega\right)
\end{aligned}
$$

したがって, 円板の上下端の速度差は

$$
\Delta u=(\beta-\omega) d_{s} \cos \theta
$$

となる.このとき, 球の回転によって生ずる揚力 $L_{r}$ を， 各円板のまわりの循環による揚力の和として表わすと, 次式で与えられる。

$$
\begin{aligned}
& L_{r}=\rho\left(u_{c}-\frac{\omega d_{s}}{2}\right) \int_{-\pi / 2}^{\pi / 2} 2 \pi\left(\frac{d_{s}}{2} \cos \theta\right)^{2} \omega \frac{d_{s}}{2} \cos \theta d \theta \\
& =\frac{\pi}{3} \rho\left(u_{c}-\frac{\omega d_{s}}{2}\right) \omega d_{s}^{3}
\end{aligned}
$$

$$
C_{L_{r}}=\frac{L_{r}}{\frac{1}{2} \rho u_{c}{ }^{2} \pi a^{2}}=\frac{8\left(u_{c}-\frac{\omega d_{s}}{2}\right) \omega d_{s}}{3 u_{c}^{2}} \ldots . .
$$

式 (18) は Rubinow らొの回転球の理論式と同型で あることは興味深い. 図一17 は, Eichhorn らによる Sphere No. $1(0<\omega<4.84 \mathrm{rad} / \mathrm{sec})$ と Sphere No. 2 $(0<\omega<2.52 \mathrm{rad} / \mathrm{sec})$ の実測回転角速度 $\omega$ を用いて式 (19) より計算した $C_{L r}$ と, それらの計算値に対応する Eichhorn らの実測值 $C_{L}$ の比較を示す. 理論值は, か なり粗い仮定を含むにもかかわらず，実測值に比較的よ い説明を与えている. 理論值が実測值よりやや大きいの は次の理由によると思われる. 球の場合には上流側から 球の全周にわたって流体を下流に送りこめるが, 円板の 集合の場合には上面と下面からのみ送りこむ. したがっ て, 球のほうが円板の集合よりも圧力分布を, 一様化し やすいため，実測值の揚力が計算值よりも小さめにな る.

図-17 では, Eichhorn らの Sphere No. 3 と Sphere No. 4 の実験值が除外されている. Sphere No. 3 と Sphere No. 4 の実験值は, 回転角速度がそれぞれ (8 $\mathrm{rad} / \mathrm{sec}<\omega<34 \mathrm{rad} / \mathrm{sec})$ と $(3.2 \mathrm{rad} / \mathrm{sec}<\omega<14.6$ $\mathrm{rad} / \mathrm{sec}$ ) で高く式 (19) では，揚力は過大にみつもら れる.このことは, 球の回転数が低いらちは, 揚力が $\omega$ に比例して増加し, 回転数が高くなると回転が球の揚力 にそれほど効果的に寄与しないことを意味する.

式（18）を揚力係数で表わすと, 式（19）となる. 


\section{（3）抗力と揚力の関係}

揚力が正の領域では, 速度勾配と壁の存在が抗力と揚 力にはたす役割りは同じであるので抗力と揚力の間には 一定の関係があると考えられる. 式 (15) と式(17)から

$$
\frac{C_{L B}}{C_{D C}-C_{D O}} \propto\left(\frac{d u}{d y} \cdot \frac{d_{s}}{u_{c}}\right)^{3 / 2} / R_{e c}
$$

の関係が得られる.ここに式 (20) を比例関係であらわ したのは次の理由による.才なわち, 式 (15), (17) は いずれも，あるばらつきをもった実測值の平均を表わす 関係式であり, したがって両式の比が，必ずしも $C_{L B} /$ $C_{D C}-C_{D O}$ の実測值の平均值を表わすとは限らないた めである. 式 (20) 中の無次元量の関係を実験值を用い て検証したのが 図一18である.式（20）は，層流せん 断流中のシアー効果による抗力の増分に対する揚力の関 係をかなり適切に説明しているといえよう. ある $R_{e c}$ を もつ粘性一様流中の球は, $C_{L}=0, C_{D C}=C_{D O}$ をもち, このとき $d u / d y=0$ である. 一様流では, 式 (20) は $0 / 0=0$ となる. しかし, 式 (20) は,このような特別 な流れの条件に対し導かれたものではない. 式 (20)は, ある $R_{e c}$ をもつ壁のある層流せん断流れの中に球があ るとき, 速度勾配は, 抗力の増加よりも揚力の増加に強 く影響することを示していると解釈すべきである.

\section{5. 結語}

本研究は, 壁面と速度勾配が存在する自由表面のある 層流せん断流中に球が静止しているとき, 球に作用する 抗力と揚力を調べたものである. 同時に, 流体力に及ぼ 寸水面の影響も検討されている. 実験の $R_{e c}$ の範囲は (10〜100) であり, Eichhorn らによる円管内層流中で 回転自由な球の抗力と揚力の測定值との比較も行われて いる.ここで報告されている測定值の信頼性は十分高い が, 得られた結果は, 実験が行われたレイノルズ数の範 囲について成立するものであり，この範囲を越える層流 せん断流中の球の流体力については, さらに検討が望ま れる。

本論で求められた揚力について若干説明を加える必要 がある. 前述のように, 球は水面の変形によって下向き の力を受ける. 一方, 底面の存在は球に上向きの力を及 ぼすので, 球に作用する鉛直方向の力は, この 2 つの相 反する方向をもつ力の合成である. したがって, 特に, 揚力の符号を変える付近では，両者の影響が加わって掦 力の大きさが決っている. 水面の影響が下向きに及ぶ範 囲と底面の影響が上向きに及ぶ範囲は，球径を一定とす ると, 水深の大きさにも関係する.このとき, 揚力は $h / d_{s}$ に関係する. 本論では, $h$ を一定に保ち, $d_{s}$ を

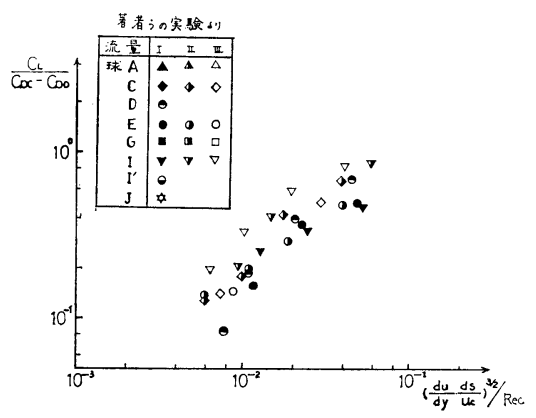

図一18 せん断流中の抗力と揚力の関係

変化させて実験を行ったため, 揚力に及ぼす水深の影響 を明確には見積れなかったが，この点に関してさらに検 討する必要があろう。

本文で得られた主要な結論を列挙すると次のとおりで ある.

1）層流せん断流中の坑力は，無限の広がりをもつ一 様流中の抗力よりも大きく, その差は, 低 $R_{e c}$ で著し く, $R_{e c}$ の増大につれて相対的に小さくなる.

2）抗力は, 次の 4 つの情報が与えられると一意的に 決定できる（図一10).

(i) 流体の物理特性

(ii) 最大流速または流量

(iii) 球の直径

(iv) 球の壁からの相対位置 $\left(\eta_{c}=y_{c} / h\right)$

3) せん断流中の球の抗力係数 $C_{D C}$ から, 同じ $R_{e c}$ の一様流中の球の抗力係数 $C_{D O}$ を取り除いたものは, 壁と流速分布の影響を考慮にいれたシアーパラメーター で決定できる．この関係式は

$$
C_{D C}-C_{D O}=32\left\{\frac{d u}{d y} \frac{d_{s}}{u_{c}} \frac{1}{\left(R_{e c}\right)^{2}}\right\}^{1 / 2}
$$

で与えられる。

4）自由表面のある層流せん断流中の揚力は，底面近 くでは上向きに（正の揚力）, 水面近くで下向き（負の 揚力）に作用し, 実際の揚力場は, 両者の重ね合せで決 っている.

5）下向き揚力の発生原因は, 球の存在による水面の 変形によって誘起される反力である.これは実験によっ て確かめられた. 揚力の符号の変化する位置は, 球の大 小に関係し, 大きい球のほうが水面側で起る.

6) 回転しない球の正の揚力は, 次式で近似すること ができる.

$$
C_{L B}=\frac{L_{B}}{\frac{1}{2} \rho u_{c}^{2} \pi a^{2}}=18\left(\frac{d u}{d y} \frac{d_{s}}{u_{c}} \frac{1}{R_{e c}}\right)^{2}
$$

7) 回転数が $5 \mathrm{rad} / \mathrm{sec}$ 以下で回転する球の揚力は, 球を円板の集合と考えて求めた循環の和から求まる. し かし, 回転数が高くなると理論は実験值を説明し得な 
い.これは, 回転数が高くなると, 揚力が回転数に比例 するほど増大しないためである.

8）シア一効果による抗力の増大に対する揚力の比を 表わす関係式が求められた. この関係式は, ある $R_{e c}$ を もつ壁のある層流せん断流れの中に球があるとき, 速度 勾配は, 抗力の増加よりも揚力の増加に強く影響するこ とを示す.

\section{参考文 献}

1) Goldstein, S. : Modern developments in fluid dynamics, Vol. 2, Dover, 1965.

2) Saffman, P.G.: On the motion of small spheroidal particles in a viscous liquid, J. Fluid Mech. Vol. 1, 1956.

3) Bretherton, F.P. : The motion of rigid particles in a shear flow at low Reynolds number, J. Fluid Mech., Vol. 14, 1962.

4) Happel, J. and Brenner, H. : Low Reynolds number hydrodynamics, Prentice-Hall, 1965.

5) Segré, G. and Silberburg, A. : Behavior of macroscopic rigid spheres in poiseuille flow, Part 2. Experimental result and interpretation, J. Fluid Mech., Vol. 14, 1962.
6) Saffman, P.G. : The lift on a small sphere in a slow shear flow, J. Fluid Mech., Vol. 22, Part 2, 1965.

7) Rubinow, S.I. and Keller, J.B. : The transverse force on a spinning sphere moving in a viscous fluid, J. Fluid Mech., Vol. 11, 1961.

8) 例えば Jensen, V.G. : Viscous flow round a sphere at low Reynolds number <40, Proc. Roy. Soc. London, Series A, 249, 1959.

9) Fayon, A.M. and Happel, J. : Effect of a cylindrical boundary on a fixed rigid sphere in a moving viscous fluid, A.I.Ch.E. Journals, Vol. 6, No. 1, 1960.

10) Young, D.F. : Drag and lift on spheres within cylindrical tubes, J. of Hydraulics Div., Proc. ASCE, HY. 6, June, 1960.

11) Eichhorn, R. and Small, S. : Experiments on the lift and drag of spheres suspended in a poiseuille flow, J. Fluid Mech., Vol. 20, 1964.

12) Lamb, H. : Hydrodynamics, 6th ed. Cambridge Univ, Press, p. 616, 1932.

13) Moor, F.K. : Theory of Laminar Flow, Princeton Univ. Press, 1964.

14）水理公式集：昭和 46 年度改訂版, 土木学会編, p. 411, 1971.

(1977.7.22 - 受付) 